\title{
Implementation of Curriculum Components at Primary School (SDN) Ketawanggede Malang, Indonesia
}

\author{
Lely Mifthachul Khasanah \\ Department of Education Administration \\ Universitas Negeri Malang, Indonesia \\ lelymk2.1901328@students.um.ac.id
}

\author{
Mustiningsih \\ Department of Education Administration \\ Universitas Negeri Malang, Indonesia \\ mustiningsih.fip@um.ac.id
}

\author{
Hiyasintus Ile Wulogening \\ Department of Education Administration \\ Universitas Negeri Malang, Indonesia \\ hiyasintus.1901328@students.um.ac.id
}

\begin{abstract}
This research is qualitative research that aims to determine the implementation of curriculum components at (Primary School) SDN Ketawanggede Malang, along with obstacles and problem solving. Research focuses on curriculum components related to implementation, constraints, and problem solving. Researchers try to enter naturally and give a message as a key instrument and select informants who know very well about the focus of the study. The informants of this research are the teacher, the deputy head of the curriculum section school, and the head of the SDN Ketawanggede Malang. The data source of this research is the data of interviews and observations (primary data) and documentation (secondary data). Data in this study were collected through in-depth interviews, observation, and documentation. Data were analyzed through three stages, namely data reduction, data presentation, and conclusion drawing. The results showed that the curriculum components which included the objectives, content, methods, and evaluation have been implemented well by SDN Ketawanggede Malang. This is proven by the achievement of the objectives of the curriculum and programs launched by schools. In its implementation, things still felt that needed to be changed or improved in order to achieve the national goals of education and improvement in accordance with existing field conditions. The results of this study are expected to be used as an evaluation or consideration for related parties as an effort to improve the implementation of curriculum components at SDN Ketawanggede Malang.
\end{abstract}

Keywords: curriculum components, constraints, problem solving

\section{INTRODUCTION}

In the world of education, all activities carried out lead to the curriculum (Katuuk, 2014). Romine (1954) opinion regarding the curriculum, as above, implies that the notion of the curriculum not only consists of subjects, but all activities and experiences that are the responsibility of the school, including extracurricular activities; curriculum implementation is not limited to the classroom wall, but can be implemented outside the classroom in accordance with the objectives to be achieved; delivery systems used by teachers should be adapted to the conditions of students; the purpose of learning is not to convey subjects only, but to shape the child's personality and learn how to live in society.The learning program contained in the curriculum has been planned systematically by educational institutions to smooth the learning process in order to achieve educational goals (Hamalik, 2017).

According to Ludwig Von Bartalanfy in Hamalik (2013), the system is a set of elements that are bound together in a single unit and among those elements there is a relationship with the environment. According to Anatol Raporot in Hamalik (2013), the system is a collection of unity and set of relationships with each other. Meanwhile, according to L. Ackof in Hamalik (2013), the system is every conceptual or physical unit consisting of parts, in a state of interdependence with each other. When referring to KBBI, the system is a set of elements that are regularly interrelated to form a totality. From this explanation, the system can be interpreted with a broader basic concept, namely; a network that consists of a number of components that interact with each other, work together to form a single unit. While the curriculum consists of components that are interrelated with one another and have a purpose, namely, objectives, content, strategies / methods, and evaluation (Hamalik, 2013). Thus, the curriculum can be said as a system because there are a number of components that are interrelated and bound, and have the same goal.

Curriculum renewal needs to be done considering there is no one curriculum that is suitable all the time (Yulianto, Roesdiyanto, \& Sugiharto, 2017). The curriculum must always be updated in line with changes to remain relevant to a changing society (Prihantoro, 2014). Curriculum changes can be partial, namely to certain components, or overall that involves all curriculum components (Arifin, 2011). After being developed and updated, the curriculum will not be achieved if it is only left in its implementation. Changes to the existing curriculum have not been implemented to the maximum (Yulianto et al., 2017).

The implementation of each component will determine whether or not the curriculum program is achieved so that the implementation will require the organization of all its components (Mualimin, 2012). This implementation also involves broad actions which are the interaction of processes between those who create the program and those who implement the program. Therefore, managers of educational institutions must be able to manage education and the curriculum (Mendikbud, 2014). The teachers were assisted and guided to implement the curriculum by the instructor teachers in the classroom which were called on-service training and there were also monitoring and evaluation processes during the 
implementation done by independent assessors (Suyanto, 2017). Preliminary studies in the field suggest that the application of the curriculum, along with its components, cannot always achieve the objectives of the curriculum so that a review is needed to improve and update the curriculum.

Leading schools are schools that have a positive image capable of delivering their students to achieve the national goals of education through learning with the application of a correct and good curriculum (Syed Alwi \& Kitchen, 2014). SDN Ketawanggede Malang, as one of the leading elementary schools in Malang, has proven itself capable of competing and innovating in its efforts to implement the curriculum properly and well. In order to make changes and improvements to the curriculum in schools, researchers are interested in examining the implementation of curriculum components that have been implemented by SDN Ketawanggede Malang.

\section{METHOD}

This research uses a qualitative approach. This is done because in this study the researcher tried to explain the reality in the field without presenting figures in his presentation. Researchers also try to describe all aspects that occur in the field as clearly as possible. Research focuses on curriculum components, which consist of objectives, content, methods, and evaluation; related to the implementation, constraints, and problem solving.

The data source of this research is the data of interviews and observations (primary data) and documentation (secondary data). Data in this study were collected through in-depth interviews, observation, and documentation. Data were analyzed through three stages, namely data reduction, data presentation, and conclusion drawing. Researchers try to enter naturally and give a message as a key instrument and choose informants who know very well about the focus of research. This research was conducted at SD Negeri Ketawanggede Malang. This school is one of the top primary schools in Malang.

\section{RESULTS AND DISCUSSION}

In accordance with Ministry of Education and Culture regulations, SDN Ketawanggede this year implemented the 2013 curriculum. In addition, SDN Ketawanggede also implemented several programs included in the curriculum, based on the vision and mission of the school. One of them is SEKAM which is based on the Adiwiyata School Program. SEKAM stands for waste, energy, biodiversity, water and food (free of 5P). Garbage here means students must maintain environmental sustainability and can process waste appropriately.

Energy here means students are taught to save energy by turning off lights when not in use, using Solar Power Plants (PLTS) as an energy source and as a source of student learning at school. Biodiversity means that students are taught to love animals and plants in their environment. Water here means that students must save water in its use. Food here is intended that food in school is healthy food that does not contain 5P, namely flavour enhancers, sweeteners, preservatives, colourings, and thickeners. From the explanation above, the activities at SDN Ketawanggede Malang are in accordance with curriculum objectives and school goals. In 2019, learning at SDN Ketawanggede Malang must take part in the Strengthening of Character Education (PPK) program. This is consistent with studies conducted by Ika \& Putranti (2019). According to the speaker who is a grade 6 teacher at SDN Ketawanggede Malang.

This change has a significant influence on changes in the format of the RPP column that must be added to the KDP column and new habituation of learners' activities in the context of implementing KDP. PPK contains the main values of religious, nationalist, independent, mutual cooperation, and integrity (Ika \& Putranti, 2019). Furthermore, the principal of SDN Ketawanggede Malang explained that the daily activities of students in the school also refer to the KDP as: (1) habituation of dhuhur prayers which is usually done by themselves classy, then it is held in congregation by all students together with the teacher, (2) habituation of reading $\mathrm{Al}$ Quran in the morning, reading asmaul husna, and daily prayers, (3) holding morning apples, respecting the flag, singing the national anthem, and (4) habituating class pickets, tidying shoes, picking up trash in front of the class.

In classroom learning activities, teachers at SDN Ketawanggede Malang have implemented learning in accordance with the applicable curriculum, the 2013 curriculum. However, in grade 6 , due to the high demands for material exploration for the preparation of the National Examination (UN), learning that only refers to the 2013 curriculum deemed insufficient. Therefore, grade 6 learning also uses KTSP curriculum to meet material exploration needs. In addition, the informant emphasized that innovation from teachers was needed to develop material from various sources in order to meet the needs of 6th grade students to prepare for the national examination.

So that the delivery of material in the class can run smoothly, maximally and achieve learning goals, of course teachers are needed to master the material and supporting facilities and infrastructure (Krissandi \& Rusmawan, 2015). When researchers make observations, it appears the classroom atmosphere is very supportive of learning activities. In addition, the data and observations show that the competence of teachers in teaching is also in accordance with their fields. Even in schools there are learning media that can be used by students such as the Solar Power Plant, which has illuminated 8 classes, catfish ponds, aquaponic, bio pore, photocell, and biogas.

According to the teacher who teaches at the school, these learning media really help teachers and students in the learning process that is meaningful and applicable. However, based on the results of interviews and observations found several things that still need to be improved in order to support the learning process, such as there are still classes that do not have projectors as teaching aids in class. In addition, some teachers still need to increase their knowledge in guiding children with special needs to the maximum.

Cooperation that has not been maximized with parents regarding student activities at home is also one factor, so learning in the classroom is not running optimally. On the other hand, teachers also still need to improve innovation in developing learning materials and methods. Even so, the school has made efforts for 
improvement and development, such as making plans to provide facilities and infrastructure regarding projectors which in one year buy at least one projector until it is available in all classes; building positive communication and equalizing views with parents by inviting them to school; encouragement from school principals to improve competence and become model teachers; and relocation of the principal's office and teacher's room to improve the rhythm and quality of cooperation between teachers accompanied by the principal.

Evaluation is carried out in two processes, namely evaluation of student learning outcomes and evaluation of the curriculum (Valcke, Rots, Verbeke, \& van Braak, 2007). In carrying out an evaluation or assessment of student learning outcomes, the teacher refers to the assessment in accordance with the 2013 curriculum. This is in accordance with the Implementation of the 2013 Curriculum.

One thing that is noted by researchers, the analysis of questions is still a major topic that cannot be carried out to the maximum by the teacher in general, when conducting assessments. This is caused by the time factor and systematic analysis of the questions that require sufficient attention of the teacher. In carrying out curriculum evaluation, the findings that are found by the teacher immediately become notes for the teacher as improvements that will be made in the next program, both improvements and improvements. The lack of initiative and opportunities for teachers to share learning in class both related to constraints and other things that can be used as an opportunity to evaluate the existing curriculum.

\section{CONCLUSION}

The renewal of the curriculum is a natural thing considering the development of the times continues to occur and society is developing. Curriculum components covering objectives, content, methods, and evaluations have been implemented well by SDN Ketawanggede. This is proven by the achievement of the objectives of the curriculum and programs launched by schools. In its implementation, things still felt that needed to be changed or improved in order to achieve the national goals of education and improvement in accordance with existing field conditions. Changes that occur, curriculum renewal, is not something that is certain will not happen.

The researcher suggests the following things as improvements to the constraints that occur to: (1) increase innovation and creativity in analyzing questions so that implementation is easy and does not require a long time, (2) building positive communication and fostering good relations with parents continuously to develop students' potentials, and (3) increase teacher innovation and creativity in developing subject matter and teaching methods and how to effectively assist students with special needs, by holding sharing activities among colleagues. In addition, researchers hope that the results of this study can be an evaluation or reference for related parties for further improvement or research.

\section{REFERENCES}

[1] Arifin, Z. 2011. Konsep dan Model Pengembangan Kurikulum. Bandung: Remaja Rosdakarya.

[2] Ika, M. M., \& Putranti, Y. D. 2019. Penerapan Program Penguatan Pendidikan Karakter Berbasis Kelas di Sekolah Dasar Se-Kecamatan Sleman Kabupaten Sleman. Elementary Journal, 2(1), 42-52.

[3] Hamalik, O. 2013. Manajemen Pengembangan Kurikulum. Bandung: Rosdakarya.

[4] Hamalik, O. 2017. Dasar-Dasar Pengembangan Kurikulum. Bandung: Rosdakarya.

[5] Implementasi Kurikulum (2013). Kemendikbud RI

[6] Katuuk, D. A. 2014. Manajemen Implementasi Kurikulum: Strategi Penguatanimplementasi Kurikulum 2013. Jurnal Cakrawala Pendidikan, 33(1). https://doi.org/10.21831/cp.v1i1.1858.

[7] Krissandi, A. D. S., \& Rusmawan, R. 2015. Kendala Guru Sekolah Dasar dalam Implementasi Kurikulum 2013. Jurnal Cakrawala Pendidikan, 34(3). https://doi.org/10.21831/cp.v3i3.7409

[8] Moleong, L, J. 2015. Metodologi Penelitian Kualitatif. Bandung: PT Remaja Rosdakarya.

[9] Mualimin, M. 2012. Implementasi Kurikulum Pendidikan Agama Islam (PAI) di SMP Negeri 1 RSBI Kota Magelang. Master thesis, IAIN Walisongo.

[10] Pramono, S. 2014. Panduan Evaluasi Kegiatan BelajarMengajar. Jogjakarta: Diva Press.

[11] Prihantoro, C. R. 2014. The Perspective of Curriculum in Indonesia On Environmental Education. International Journal of Research Studies in Education, 4(1). https://doi.org/10.5861/ijrse.2014.915.

[12] Romine, S. 1954. Building the High School Curriculum. New York: The Ronald Press Company.

[13] Suliana, N. 2013. Dasar-Dasar Proses Belajar Mengajar. Bandung: Sinar Baru Algensindo.

[14] Suyanto, S. 2017. A Reflection On the Implementation of a New Curriculum in Indonesia: A Crucial Problem On School Readiness. AIP Conference Proceedings, 1868(1), 100008. https://doi.org/10.1063/1.4995218.

[15] Syed Alwi, S. F., \& Kitchen, P. J. 2014. Projecting Corporate Brand Image and Behavioral Response in Business Schools: Cognitive or Affective Brand Attributes? Journal of Business Research, 67(11), 23242336. https://doi.org/10.1016/j.jbusres.2014.06.020.

[16] Ulfatin, N. 2013. Metode Penelitian Kualitatif di Bidang Pendidikan: Teori dan Aplikasinya. Malang: Media Nusa Creative.

[17] Valcke, M., Rots, I., Verbeke, M., \& van Braak, J. (2007). ICT Teacher Training: Evaluation of The Curriculum and Training Approach in Flanders. Teaching and Teacher Education, 23(6), 795-808. https://doi.org/10.1016/j.tate.2007.02.004.

[18] Yulianto, S., Roesdiyanto, R., \& Sugiharto, S. 2017. Analisis Perubahan Kurikulum pada Proses Pembelajaran Pendidikan Jasmani Olahraga dan Kesehatan di Sekolah Dasar. Jurnal Pendidikan: Teori, Penelitian, dan Pengembangan, 2(1), 130-140. https://doi.org/10.17977/jp.v2i1.8477. 